Intervirology 1979;12:280

\title{
Some Unclassified Viruses and Virus-Like Agents
}

For many viruses and virus-like agents, the data on characterization are inadequate at present to allow for sound classification. Some of the most important and interesting of these are listed below:

Human hepatitis B virus

Marburg/Ebola

Infectious pancreatic necrosis virus offish, bursal disease virus of chickens, and similar viruses from arthropods

Agents of scrapie (and transmissible mink encephalopathy), Kuru, and Creutzfeldt-Jakob diseases

Viroids

Borna disease virus

Agent of roseola infantum (or exanthum subitum, or sixth disease)

Agent of cat-scratch disease

Drosophila $\sigma$ virus

Satellite viruses in plants

Satellite RNAs in plants 